\title{
Post-Merger Strategy and Performance: Evidence from the US and European Banking Industries
}

\author{
Jens Hagendorff* \& Kevin Keasey \\ Leeds University Business School, Maurice Keyworth Building, \\ The University of Leeds, LS2 9JT, Leeds, UK
}

\begin{abstract}
The banking industry has one of the most active markets for mergers and acquisitions. However, little is known about the type of operational strategies adopted by banking firms in the years following a deal. For a sample of bidding banks in the US and Europe, this study compares the design and performance implications of different post-merger strategies in both geographic regions. Using accounting data, we show that European banks pursue a cost-cutting strategy by increasing efficiency levels vis-à-vis non-merging banks and by cutting back on both labor costs and lending activities. US banks, on the other hand, raise both interest and non-interest income in the post-merger period.
\end{abstract}

JEL classification: G21, G34, G28

Keywords: mergers, acquisitions, banks, strategy, long-term performance, US, Europe

* corresponding author. Tel.: +44 (0)113 3434483, email: juh@lubs.leeds.ac.uk 


\section{$1 \quad$ Introduction}

Over the last two decades, banks have undergone a rapid process of asset consolidation. With a combined acquisition value of roughly \$2 trillion US\$ between 1986 and 2006 (Thomson Financial), the banking industry is one of the most active industries in terms of mergers and acquisitions (M\&A). Yet, little is known to date about the specific post-merger strategies adopted by banks and their performance effects. The purpose of this study is to analyze the operational strategies adopted by a sample of US and European banks using accounting data in order to compare the long-term performance of acquisition strategies in both geographic regions.

A substantial body of research examines the performance effects of bank mergers and finds no evidence of merger-related performance improvements as measured by ROA (Zollo and Singh 2004; Houston et al. 2001; Ramaswamy 1997; DeLong 2003), ROE (Altunbas and Ibanez 2004; Akhavein et al. 1997) or operating income profitability (Lindner and Crane 1993). For Europe, the evidence is mixed. Some studies document profitability gains for merged banks (Cornett et al. 2006; Campa and Hernando 2006), while others (Altunbas and Ibanez 2004) cannot find any merger-related improvements in operating performance for a sample of European credit institutions.

Berger et al. (1999) argue that M\&A are banks’ strategic answer to changes in their industry environment. In this paper, we contrast the post-merger strategies of US banks to those adopted by European institutions. As well as a number of structural differences (e.g., the extent of state-control of banks in some European countries, the relative importance of banking to securities markets), banking firms in Europe and the US also differ in terms of specific 'exogenous shocks' experienced by banking firms. In the US, a series of deregulatory measures culminated in the 1999 Gramm-Leach-Bliley Act that allowed banks, for the first time since the 1930s, to engage in a wide range of financial services (ranging from deposit taking to investment banking and insurance) and, effectively, introduced universal banking to the US. In Europe, by contrast, the introduction of the Euro, through its effects on the integration and 
growth of capital markets in the Euro zone, has led to enhanced competitive pressures for banks from both capital markets (which increasingly challenge the role of banks as the main financial intermediaries (Eisenbeis and Kaufman 2006)) and from customers (who find it easier to compare rates and fees across borders (Allen and Song 2005)). Coupled with emerging shareholder activism and the evolving role of the state as owner and/or guarantor of banks in economies such as Italy, France and Germany, European banking firms find themselves under growing pressures to increase efficiency (White 1998).

We examine post-merger strategies consistent with two of the most frequently cited strategies behind M\&A: to cut costs (e.g. by economizing on labor costs or branch networks) and to increase revenue (e.g. by selling different types of financial products or by increasing lending).Whilst we do not analyze data on the motivation behind individual transactions (see for example Houston et al. 2001, who collect this information from the press coverage preceding M\&A deals), inferences about ex-ante motivations behind M\&A are made using ex-post merger results. Consequently, we argue that differences in the average postmerger performance of acquiring banks in the US and Europe, reflect different pre-merger motivations behind the average M\&A deal.

The main findings of this study may be summarized as follows. There is some evidence consistent with European banks pursuing a cost-cutting strategy during the three years following a merger. Specifically, banks in Europe manage to reduce non-interest expenses and, to some extent, retreat from lending activities in the post-merger period. US bidders, by contrast, engage in a revenue-enhancement strategy that entails increasing their on- and off-balance sheet activities. Further, we find that European bank mergers produce small performance gains for acquiring banks in the post-merger period, while US acquirers do not experience any changes in performance as a result of M\&A. The profitability gains of European credit institutions are particularly pronounced for product diversifying and cross-border mergers. Finally, the results also show that it takes three years before performance gains from cross-border mergers materialize. 
Our study makes a number of contributions to the literature on strategy and performance. First, we show that different types of merger strategies are predominant in Europe and the US. Relatedly, this paper, for the first time, directly compares the merger performance of European and US bank M\&A. Europe has received relatively little academic attention as bank M\&A studies largely focus on the US market. Second, we show that conclusions based on an US market context do not necessarily apply to markets outside the US. Thus, we can verify a number of 'stylized facts' that have emerged from the US literature for our sample of US banks (e.g., bank mergers tend to be performance neutral, bidding banks are strong performers in the pre-merger period), but not for the European subsample. For example, we find that European bank M\&A generate profitability increases in the post-merger period and that bidding banks are only weakly-performing against their peers prior to M\&A.

Third, the results we report show that the type of cost-cutting strategies adopted by European banks are more successful than revenue-increasing strategies that US institutions adopt following M\&A. This could be due to European banking firms, because they are relatively less efficient vis-à-vis US institutions (Bos and Kolari 2005), having more potential to realize costs efficiencies. Alternatively, there are a number of difficulties associated with revenue increases when the provision of additional services raises costs and leads to lower profitability (Berger and Mester 2003). Finally, our results control for a mean reversion trend in performance data (i.e. the phenomenon that above-industry performance of bidding firms tends to revert to zero in the post-merger period) by adjusting bidding banks’ data using a sample performance-matched banks (see Knapp et al. 2006; Barber and Lyon 1996).

The remainder of this study is organized as follows. The next section introduces the M\&A sample and research strategy. Section 3 analyzes the specific strategies adopted by banking firms in Europe and the US. Section 4 presents findings regarding the profitability effects of bank M\&A and Section 5 analyzes the timing of performance changes in a linear regression framework. 


\section{$2 \quad$ Data and Research Design}

\subsection{The M\&A Sample}

The sample of bank acquirers was obtained from Thomson Financial’s M\&A database (SDC Platinum).

We impose the following data restrictions:

1. Sample M\&A deals are majority acquisitions (i.e. which resulted in the acquirer having a stake of at least 50\% in a target institution) that were announced during $1996-2004$.

2. The value of M\&A transactions is at least 100 million in constant 1996 USD.

3. Acquiring banks are exchange-listed in Europe (EU-15 plus Switzerland) or the US and have complete accounting data available on Worldscope and Fitch's Bankscope database for the fiscal years $t-1$ and $t+3$ surrounding the completion year of a merger $(t=0){ }^{1}$

4. While acquirers are commercial banks, bank holding companies and credit institutions, targets may also be insurance companies (life and non-life), mortgage bankers, as well as security brokers and flotation companies. Accordingly, we can assess the performance effects of consolidation across different financial product markets.

5. Cases where acquirers completed more than one merger per fiscal year are deleted. ${ }^{2}$

Table 1 reports the sample acquisitions by geographic origin of the bidding bank (Panel A) and by merger completion year (Panel B). Overall, 70\% of deals have been initiated by banks in the US. The UK, Belgium and Italy each make a sizable contribution to the European bank merger sample. A high number of M\&A deals were completed in the period 2000 - 2002 with a noticeable slowdown in 2003 that was subsequently followed by increases in merger activity.

\footnotetext{
${ }^{1}$ For two cases, where the fiscal year-end is before 31 December and after the merger completion date supplied by Thomson Financial, the following fiscal year is employed as year 0 .

${ }^{2}$ In unreported tests, we analyze differences in profitability between single-M\&A transactions and higher order deals. We find little evidence pointing to serial acquisitions having performance effects that are different from those of single bids. On the other hand, multiple acquisitions by European banks attract a significantly smaller increase in market-adjusted OPCFROA than single acquirers (statistically significant at the 5\%-level).
} 
[Table 1 near here]

\subsection{Operating Performance Changes}

We isolate merger- and bank-specific effects on financial performance from phenomena that affect the entire industry or economy by comparing bidding bank performance against two benchmarks. First, financial performance data are measured against asset-weighted mean values of non-merging banks listed on Worldscope in the bidder's country to obtain market-adjusted returns. ${ }^{3}$ Second, acquiring banks are matched on the basis of size and pre-merger performance as described in Barber and Lyon (1996) and Loughran and Ritter (1997) to yield performance-adjusted returns. Matched banks are selected on the basis of

1. geography (matched banks are listed on the same exchange as acquiring banks),

2. industry (defined at the 2-digit SIC level),

3. size (a filter of $25 \%$ to $200 \%$ of acquiring bank assets during year 0 is applied) and

4. pre-merger profitability. OPCFROA are pre-tax operating cash flows over the book value of assets (defined in Section 4). For every sample bank $i$, the credit institution closest in terms of its OPCFROA is selected as the matched institution.

5. Finally, matched banks must not have acted as acquirers themselves in any M\&A deals valued at more than $\$ 100$ million up to five years before the focal transaction.

We employ performance-adjusted returns, because bidding firms tend to outperform the general market before a merger. As above-industry performance reverts to zero in the years following a merger, studies based on industry-adjusted data may wrongly interpret reverting mean performance as M\&A having negative performance effects (Ghosh 2001). Knapp et al. (2006), for example, find evidence of a mean reversion trend in industry-adjusted returns for a sample of bank mergers. The authors report performance

\footnotetext{
${ }^{3}$ Weighting industry returns by the assets of constituent banks means that larger banks have a bigger impact on the benchmark return. This is appropriate given our sample contains relatively large bank acquirers.
} 
losses when measuring post-merger profitability against its historic values and profitability increases after correcting for a reverting mean in performance data.

\section{$3 \quad$ Post-M\&A Strategies: Cost Savings v. Revenue Enhancements}

Merger strategies vary for individual deals and include raising market power (Berger et al. 1998; Bikker and Haaf 2002), responding to industry deregulation or technological progress (Berger and Mester 2003), or averting distress. However, among the reasons most frequently-cited by managers for engaging in acquisitive growth strategies are to cut costs and to increase revenues in the post-merger period (Amel et al. 2004; Berger et al. 1999).

We analyze post-merger strategy using a number of accounting ratios as defined in Table 2 . The data are from Fitch's Bankscope, a database which contains balance sheet and income statement data for individual banks. Four simple filters are applied to the raw data to ensure the results are not driven by missing or extreme values.

1. Accounting data are in local GAAP only. Two European banks for which data are only available in International Financial Reporting Standards (IFRS) are omitted from the sample to avoid confounding effects when credit institutions that have previously reported according to local GAAP start to report according to IFRS after 2004.

2. The consistency of the data obtained from Worldscope and Bankscope was examined. For each bidding bank, the value of total assets (Bankscope data item: 2025; Worldscope data item: WC02999) was compared and bidders omitted from the sample if there were marked differences between the values of this variable in years -2 to $+3 .^{4}$

3. Zero values for all variables were inspected and replaced with missing values if any of the underlying ratio components were missing and a value of zero, thus, not justified.

\footnotetext{
${ }^{4}$ In total, two Austrian and two Italian acquirers were omitted from the sample as a result of inconsistencies between the data available on Worldscope and Bankscope.
} 
4. The first and the $99^{\text {th }}$ percentile of the distribution of the following variables have been winsorized because of extremely high or small values: ROA, loan to equity, non-interest income to operating income, and loan loss provisions over net interest revenue.

In the US, the recent breakdown of demarcation lines between different types of financial services (above all, resulting from the Gramm-Leach-Bliley Act of 1999) has opened opportunities for depository institutions to diversify their earnings into areas such as investment banking, insurance, and asset management. Consequently, we expect that US banks will pursue a revenue-enhancing strategy after a merger. Previous studies report that US bank M\&A appear to be frequently associated with revenue enhancements (Berger and Mester 2003). Cornett et al. (2006) observe a sharp increase in off-balance sheet activities, mainly due to an increase in derivatives underwriting. Akhavein et al. (1997) and Klein and Saidenberg (2005) find that M\&A in the US is followed by sharp increases in lending activities as larger and more diversified BHCs hold advantages over geographically-focused institutions in the form of, inter alia, lower regulatory capital charges and improved geographic risk diversification. In the same vein, cost efficiency gains, though clearly a motivation behind some M\&A deals in the US (Houston et al. 2001), only materialize in the face of substantial activity overlap between bidders and acquisition targets (Ramaswamy 1997; Rhoades 1998).

\section{[Table 2 near here]}

As regards European credit institutions, on the other hand, we expect these to realize cost efficiencies following M\&A. This could be the result of growing shareholder value concerns in Continental European banking as well as pressures for European banks to become more cost efficient (White 1998), as well as the introduction of a single currency in the Euro area, and the continuing integration of capital markets (Allen and Song 2005). Consistent with our expectation, Campa and Hernando (2006) and Vander Vennet (1996) show that the profitability gains of European bank M\&A activities are mainly driven by gains in cost efficiency. 
[Table 3 near here]

Table 3 shows that, in line with our expectation, the primary motivation for European banks for engaging in M\&A is to cut costs following M\&A. European bidders manage to further widen the efficiency gap vis-à-vis national banking sectors in the post-merger period. Both employment cost per employee and non-interest expenses per employee are further reduced between years -1 and 3 ( $t$-test significant at 5\%). Further, all other market-adjusted efficiency measures improve (albeit changes in these measures are not significant at customary levels of statistical significance). Finally, European bidders further retreat from lending activities as reflected in a market-adjusted reduction in the loans-to-assets ratio of $3.17 \%$ ( $t$-statistic significant at $8 \%)$.

For US institutions, Table 3 shows that following bank M\&A, bidders increase their loans to assets ratio to a market-adjusted $2.89 \%$ (difference significant at 5\% according to both a $t$-test and a Wilcoxon rank statistic). Despite the sizeable boost in lending activities, the market-adjusted increases in capital ratios following M\&A remain relatively small ( $0.44 \%$ of Tier 1 capital and $0.22 \%$ of total capital). This suggests that the risk profile of bidding banks is not materially changed by M\&A. As well as lending, offbalance sheet activities also increase in the post-merger period. The latter is reflected in rising marketadjusted values for non-interest income and other operating income increase (changes significant at 7\% and 8\%, respectively). There is also some evidence consistent with US banks experiencing a further deterioration in cost efficiency after completion of a merger. For instance, employment costs per employee increase to above-industry levels in the post-merger period (difference statistically significant at $10 \%)$.

Table 3 also presents some preliminary findings as regards the performance effects following bank M\&A in Europe and the US. European bidders underperform national banking sectors in terms of pre-merger profitability in year -1. Market-adjusted values for ROAA, net interest margin and non-interest income are negative and statistically significant at 1\%. Yet, European banks display above-industry levels of efficiency in year -1—with pre-merger employment cost (scaled by operating expenses, non-interest 
expenses or the number of employees) lower than the market control group. The fact that bidding banks, despite high cost efficiency levels, exhibit profitability levels below the industry average suggests that bidding banks underperform the industry in terms of the revenue they generate prior to a merger. The negative market-adjusted non-interest income to assets ratio (significant at $1 \%$ ) and the negative marketadjusted net loans to total assets ratio ${ }^{5}$ (significant at 5\%) suggest the revenue weakness that European bidders experience before a deal affects both lending and non-lending activities. In the years following M\&A, ROAA and ROAE of European banks increase from $-0.85 \%$ to $-0.42 \%$ and from $-0.59 \%$ to $4.10 \%$, respectively (all performance changes are significant at least at 5\% according to the $t$-statistic and Wilcoxon rank statistic).

In contrast to banks in Europe, there is no indication of US institutions underperforming in terms of pre-merger profitability. ROAA improvements are not significantly different from the industry benchmark and industry-matched ROAE are even positive and significant at $1 \%$. On the other hand, US bidders appear to display below-industry levels of cost efficiency prior to M\&A (the industry-matched cost-to-income ratio and employment cost to operating expenses are positive and different from zero at low levels of statistical significance).

The following section offers more detailed findings on the long-term performance implications of bank M\&A in Europe and the US. The findings we present below confirm that the type of cost cutting strategy common to US institutions post-M\&A is on average associated with small gains in performance in the years following a deal. No such gains are reported for the revenue-enhancing strategies employed by credit institutions in the US.

\footnotetext{
${ }^{5}$ Lending at below-industry levels is also reflected in a negative market-adjusted loan-loss-reserves-to-loans ratio. However, the loan-loss-reserves-to-loans ratio, next to the scale of lending activities, also reflects the default risk (i.e. quality) of a bidder's loan portfolio. Consequently, more risky portfolios attract higher loan loss reserves.
} 


\section{The Performance Results of Bank M\&A}

To examine the profitability implications of bank merger activities, we analyze merger-induced changes in operating cash flows return on assets (OPCFROA). Healy et al. (1992), Cornett et al. (1998), and Cornett et al. (2006) calculate this metric as pre-tax operating cash flows divided by the book value of assets where pre-tax operating cash flows are income before taxes and extraordinary items plus debt expenses. Accounting data are obtained from Worldscope (data items numbers in brackets).

OPCFROA=(income before taxes and extraodinary items [WC01401]

+ interest expense on debt[WC0125]) / total assets[WC02999]

OPCFROA distinguishes between two types of interest expenses for banks: interest expenses resulting from (i) the financing decision and from (ii) financial intermediation (e.g. interest payments to depositors). By contrast, accounting measures that rely on earnings data (e.g. ROA and ROE) include general interest expenses which are influenced by both the method of takeover accounting (pooling $v$ purchasing) and takeover finance (cash $v$ equity) $)^{6}$ and, thus, only allow limited inferences about changes in economic performance (Cornett et al. 2006). ${ }^{7}$

\subsection{Bank Merger Performance in Europe and the US}

Table 4 presents evidence on the long-term profitability effects of acquiring banks in Europe and the US. On the whole, the results we report in this section show that the cost cutting strategy employed by European banking firms appears to lead to performance gains, while the US strategy of merger-related revenue enhancement does not lead to performance gains. Table 4 displays returns in market-adjusted

\footnotetext{
${ }^{6}$ Debt finance-due to post-merger increases in interest expenses—-lowers net income following M\&A and the purchase method of accounting is associated with higher depreciation and goodwill expenses (Healy et al. 1992).

${ }^{7}$ Rhoades (1994) demonstrates the importance of including some interest expenses in performance metrics. For US banks, he shows that, while mergers lead to reductions in non-interest expenses as a result of branch closure programmes, interest expenses may increase in the post-merger period as financial institutions substitute low-interest retail deposits with higher-interest money market deposits.
} 
form as well as in performance-adjusted form. In year -2, US bidders realize OPCFROA of 1.99\% which equals $0.56 \%$ on an industry-adjusted basis (Panel A). Performance-adjusted OPCFROA are positive and statistically significant throughout the examination period. ${ }^{8}$ Further, abnormal accounting performance remains fairly constant over the examination period with no statistically significant differences between year -1 and year 3. Thus, the market-adjusted results in the US are consistent with earlier research that finds US bidders outperform the market before M\&A, but are unable to detect improvements in financial performance after M\&A (Houston and Ryngaert 1994; Knapp et al. 2005).

\section{[Table 4 near here]}

Examining changes in performance-adjusted returns (instead of market-adjusted data) confirms our finding that US bank mergers, on average, are performance-neutral. However, in contrast to the market control group, the performance-matched control group does not point to bidders as superior performers in the pre-merger period. For instance, in year -1, merging banks' OPCFROA is $2.08 \%$ compared with $2.18 \%$ for the matched control group (difference not statistically significant for year -2 and -1 ). ${ }^{9}$

We analyze OPCFROA for European banks in Panel B of Table 4. There is evidence that European bidders display weak pre-merger performance vis-à-vis non-merging institutions. Performance-adjusted returns are $-1.15 \%$ in year -2 (significant at $8 \%$ [t-test] and $4 \%$ [Wilcoxon rank test]) and industry-adjusted returns are $-1.80 \%$ in the same year (significant below $5 \%$ according to both test statistics). While adjusted returns remain negative throughout the examination period, they lose their statistical significance in year 1 and thereafter, implying an improvement in financial performance following M\&A. A two-tailed $t$-test confirms that European bank mergers exhibit higher post-merger profitability by showing that both performance-adjusted and market-adjusted returns experience a

\footnotetext{
${ }^{8}$ With the exception of the Wilcoxon signed rank test which is not statistically significant in +3 .

${ }^{9}$ If performance-adjusted returns are lower than market-adjusted returns, this points to bidding firms being above-market performers. This finding further highlights the need to compare the performance of sample banks to a control group that has been matched on pre-merger performance to gain a more accurate depiction of corporate performance.
} 
statistically significant improvement between years -1 to 3 . However, it is interesting to note that, the European post-merger performance improvements follow weak profitability prior to M\&A.

Another interesting finding reported in Table 4 is that European banks underperform in the pre-merger period. This is at odds with US studies (Zollo and Singh 2004; Houston et al. 2001; Ramaswamy 1997; DeLong 2003). However, there is some limited evidence consistent with European banks displaying weak pre-merger performance. Campa and Hernando (2006), for example, find that bidders underperform nonbidding institutions in terms of efficiency and that bidders experience improvements in these measures post-merger. Similarly, Vander Vennet (1996) does not find any evidence that European bidding banks are stronger performers than their industry peers in up to three years leading to a deal. The discrepancies between the US and European banking literature highlight the need to critically reexamine findings of US merger studies outside their original market context.

Why is the cost cutting strategy adopted by European banks successful? One explanation could be that, because European institutions exhibit lower cost efficiency levels than their US competitors (Bos and Kolari 2005), banks in Europe have a higher potential to reap performance gains in the post-merger period compared with US banking firms which already operate at relatively high efficiency levels (Focarelli et al. 2002). A second explanation could be that the provision of additional financial services as targeted by US institutions leads to operational difficulties and, thus, to worsening performance (Berger and Mester 2003). Consequently, cost efficiencies may be easier to achieve in the time period after a merger than revenue efficiencies.

Finally, there is no evidence of a mean reversion trend in adjusted return data. Consistent with prior findings, bidding banks outperform the industry on an industry-adjusted basis; however, market-adjusted returns do not revert to zero in the years following M\&A. Consequently, while performance-matched data demonstrate that industry averages may not be entirely representative of bidding bank performance, the use of industry-adjusted data does not bias the conclusions reported in Table 4. 


\subsection{Geographic Diversification and Bank Merger Performance}

While economic theory predicts that multinational banks hold advantages in factor, product and capital markets, cross-border deals a priori offer less scope for cost savings than domestically-oriented merger activity (Amihud et al. 2002). However, recent advances in IT and telecommunications technology (Berger and DeYoung 2001) as well as various policy initiatives at EU-level designed to stimulate crossborder bank mergers (Goddard et al. 2007) may well have reduced the inefficiencies associated with managing banking assets across borders. Further, cross-border M\&A may give acquirers access to favorable regulatory regimes. This may be particularly beneficial to banks domiciled in European countries with rigid labor laws (e.g., Germany and Italy) which may gain access to lightly regulated environments such as the US and the UK (Focarelli et al. 2002). Our sample does not contain any cross-border deals initiated by US banks. ${ }^{10}$ We hold no a priori expectations as regards the performance of European cross-border deals.

The long-term profitability implications of domestic and cross-border mergers are presented in Table 5. Panel A lists changes in financial performance following domestic M\&A in the US. Since all US deals were domestic, the results replicate earlier findings about merger activities in the US (Panel A of Table 4). Accordingly, industry-adjusted returns point to bidders outperforming non-bidding banks before a merger, but there is no evidence of performance increases upon completion of M\&A. Panel B of Table 5 presents performance data associated with domestic consolidation in Europe. While bidding banks' OPCFROA are lower than either the market or the performance-matched control group in all examination years, adjusted returns are not statistically different from zero at customary levels. ${ }^{11}$ Further, comparing OPCFROA between year -1 and year 3 in Europe indicates there are no performance changes associated with domestic M\&A. Thus, industry-adjusted return differences remain virtually identical over the

\footnotetext{
${ }^{10}$ The lack of US cross-border M\&A points to continued levels of overcapacity in the US banking industry; consequently, the consolidation of the domestic banking system for most US banks takes priority over foreign acquisitions strategies.

${ }^{11}$ One exception is year -2 where performance-adjusted OPCFROA are significant at the $10 \%$ level.
} 
examination period and performance-adjusted returns increase by a mere $0.19 \%$ (not significant at customary levels).

[Table 5 near here]

Panel C of Table 5 examines the effects of cross-border mergers on acquiring banks in Europe. Prior to cross-border deals, bidders display very noticeable levels of underperformance. For instance, in year -2, performance-adjusted and industry-adjusted returns are $-1.03 \%$ (statistically significant at 5\%) and $-3.41 \%$ (statistically significant at $1 \%$ ), respectively. Similar results apply to year -1 , but not to the three years following a merger when adjusted returns are not statistically different from zero. Between years -1 and 3 , European acquirers, on average, experience an increase of 1.68\% in performance-adjusted OPCFROA (Wilcoxon-rank statistic significant at 5\%, $t$-statistic at $8 \%$ ) and of $1.31 \%$ in market-adjusted OPCFROA (Wilcoxon rank statistic significant below 5\%).

It can, thus, be argued that the profitability gains in European cross-border deals are more pronounced than those of domestic bank M\&A. However, Table 5 also shows that the positive accounting returns to cross-border M\&A are due to European institutions reducing the extent to which they underperform relative to the control groups. Altunbas and Ibanez (2004) find that European bidding banks which engage in cross-border M\&A are less cost-efficient in the pre-merger period than domestically-oriented bidders. Also, Vander Vennet (1996) finds that European M\&A merely lead to a convergence in profitability between bidding banks and the industry, but not to cross-border bidders outperforming non-merging banks.

\subsection{The Performance Effects of Product Diversification}

Financial conglomeration through M\&A (e.g. when retail banks purchase institutions that underwrite debt, equity or insurance) has become a popular strategic move, not least as a result of the recent deregulation of 
such activities in most EU member states as well as the US. ${ }^{12}$ Cornett et al. (2006), Ramaswamy (1997), and Amihud and Lev (1981) find that the performance gains following product diversifying M\&A are lower than those of activity focusing deals. Further, when there is limited overlap between the activities that both merging parties engage in, merger-related cost savings are markedly lower (Hughes et al. 2003) and the costs of integration disproportionately high (Berger and Mester 1997). However, recent empirical work is challenging the view that diversification inevitably has detrimental performance effects (Klein and Saidenberg 2005; Campa and Kedia 2002). Vander Vennet (1996) finds that financial conglomerate mergers in Europe display higher profit efficiency in the post-merger period than activity focusing mergers. For the US, Klein and Saidenberg (2005) argue that diversified BHCs are able to engage in more lending and pay lower capital charges as a result of internal capital market advantages. More specifically, diversified banking firms may deploy resources to subsidiaries with capital requirements or access attractive lending opportunities based on information flows unavailable to external market participants. Consistent with these arguments, we expect that diversifying bank mergers are associated with better performance than focusing bank mergers.

Following Campa and Hernando (2004), Table 6 divides transactions in the US and Europe depending on whether the first two digits of the four-digit SIC code of the institutions involved in a transaction are identical. For instance, a bank (SIC 60_) acquiring a broker (SIC 62_) is regarded as diversification, while mergers between state banks (SIC 6021) and commercial banks (SIC 6029) are classified as productfocusing.

[Table 6 near here]

Panel A of Table 6 shows that our expectation that product diversifying bank mergers will outperform focusing mergers does not hold for US banks. The results indicate that US acquirers that engage in both

\footnotetext{
${ }^{12}$ In Europe, the Second Banking Co-ordination Directive introduced a 'single passport' in 1989 whereby European institutions only have to be chartered in a single European country in order to operate throughout the EU. In the US, GLBA removed the Glass-Steagall separation between commercial and investment banking.
} 
product focusing and product diversifying deals exhibit positive and statistically significant marketadjusted returns, but insignificant performance-adjusted returns. ${ }^{13}$ Consequently, US bidders systematically outperform national banking sectors, but not the portfolio of individually-matched credit institutions. Since market-adjusted returns remain positive over the entire examination period (i.e. a mean reversion trend in financial performance is absent), conclusions about the performance effects of financial conglomeration are not contingent on a particular control group. Most importantly, there is no evidence of a post-merger increase in OPCFROA between years -1 and 3 in the US, irrespective of whether performance data are measured against national industry sectors or performance-matched institutions.

European acquirers, by contrast, experience performance gains following product diversifying bank mergers that are in line with H3. Thus, the performance-adjusted OPCFROA associated with diversifying M\&A increase by $2.11 \%$ ( $t$-statistic and Wilcoxon rank statistic significant at 5\%) and industry-adjusted OPCFROA by $1.25 \%$ ( $t$-statistic significant at 7\%). Further, it appears that European banks engage in financial conglomeration after a period of sustained underperformance (in year -1, performance-adjusted OPCFROA are $-4.41 \%$ and industry-adjusted OPCFROA are $-3.61 \%$ ). Accordingly, one of the reasons behind the performance gains following diversification in Europe is that banks manage to close the profitability gap to non-merging institutions in the post-merger period.

A possible explanation of why European banks, but not institutions in the US, extract performance gains from diversifying mergers could be that European banks are more experienced in completing large and operationally complex deals as a result of a regulatory environment that has permitted such deals for longer (Vander Vennet 1996). In large parts of Europe, the established practice of universal banking meant that consolidation between different types of financial services providers has been a reality for many years, whilst such asset combinations have only been allowed in the US after 1999. In this context, information spillover effects from completed bank mergers in Europe may have improved the long-run

\footnotetext{
${ }^{13}$ In unreported tests of equality, no differences between adjusted values for OPCFROA values of focusing and diversifying deals were found in both the European and the US subsample.
} 
performance of combined banks in Europe. Delong and DeYoung (2007), for example, demonstrate the positive effects of 'learning-by-observing' on merger performance in the US banking industry. Delong and DeYoung proffer evidence consistent with the post-M\&A performance of deals improving if a substantial number of similar mergers have been completed in the preceding three years.

\section{Regression Analysis: The Timing of Performance Changes}

We analyze performance changes as they materialize in each of the five years following a deal, while controlling for the effects of different post-merger performance drivers in a linear regression framework. We estimate the following model.

$$
\begin{aligned}
\Delta \text { OPCFROA }_{t} & =\alpha+\beta_{1} \text { loans }+\beta_{2} \text { employment cost }+\beta_{3} \text { rel. size }+\beta_{4} \text { non-int. inc. } \\
& +\beta_{5} \text { dealvalue }+\beta_{6} \text { loss provisions }+\beta_{7} \text { cash dummy } \\
& +\beta_{8} \text { cross-border dummy }+\beta_{9} \text { US dummy }+\beta_{10} \text { target profit. } \\
& +\beta_{11} \text { product focus }+\beta_{12} \text { sector concentration } \\
& +\beta_{13} \text { sector int.margin }+\beta_{14} \text { pooling }+\varepsilon
\end{aligned}
$$

The dependent variable is the mean difference in performance-adjusted OPCFROA between the base year -1 and year $t$ (the post-M\&A years 1 to 4). On the right-hand side of (2), a cross-border dummy takes the value of 1 for acquisitions where target and acquirers are located in different countries (and 0 otherwise), and a US dummy is 1 for acquisitions by US banks (and 0 for deals by European bidders). Product focus is a binary variable that takes the value of 1 if the first two digits of the SIC code of the companies involved in a merger are identical and 0 otherwise. Further, deal-specific variables (deal value, SIC codes, etc.) which are from Thomson Financial and bank data (non-interest income, sector concentration, etc.) which are from Fitch's Bankscope database are collected in year -1 and include the following.

- Loans-to-assets ratio. Post-merger performance may vary with the type of strategies employed by bidders. The higher the share of loans of a bank's assets, the heavier its 
reliance on more traditional forms of banking business rather than on off-balance sheet activities.

- Employment cost. Total cost of employment is scaled by operating costs. It is conceivable that M\&A activity leads to a temporary increase in employment cost. For example, during the integration period, there may be a merger-induced expansion in the newly-merged bank’s workforce that will subsequently be scaled down.

- Relative size is measured as the ratio of target to bidder assets. Post-merger performance may be weaker in the case of 'mergers of equals' as a result of internal wrangling over which merger party is in control of the integration process. Alternatively, relatively larger targets may offer more opportunities to realize post-merger cost efficiencies.

- Non-interest income. The ratio of non-interest income to total operating income indicates the importance of fee-generating activities versus more traditional lending activities for a bank (Focarelli and Pozzolo 2001).

- Deal value. Post-merger performance may be weaker for larger deals as a result of the increased complexity of higher value M\&A deals (Akhavein et al. 1997). Deal value is measured as the logarithm of the dollar value of the M\&A transaction.

- Loan loss provisions. Lack of due diligence prior a deal as well as a post-merger expansion in lending activities may cause increased loan loss provisions to depress post-merger performance. This variable is expressed as a percentage of net interest revenue.

- Cash-only. This binary variable is 1 if a merger is financed by $100 \%$ cash rather than by a mix of cash and equity (in which case the variable is 0 ). The use of equity as a transaction currency is believed to signal to investors that the acquiring party deems its equity to be overvalued (Shleifer and Vishny 2003). Consequently, equity-only deals tend to be associated with non-performing M\&A (Lubatkin 1983; Kiymaz 2004). 
- With sector concentration and net interest margin, the regressions in (2) also control for two indicators of target market attractiveness. Market concentration captures the share of assets owned by the largest three banks. More concentrated markets are likely to lower bank profitability for most institutions (Bikker and Haaf 2002). Net interest margin is the average net interest revenue that local credit institutions realize expressed as a percentage of total earning assets. It is expected that more profitable markets offer more opportunities for bank acquirers to generate above-market returns (Focarelli and Pozzolo 2001).

- Target profitability is measured in terms of year -1 ROA. It is conceivable that acquiring more profitable targets leads to increased post-merger performance.

- Pooling. This binary variable takes the value 1 if acquirers use the pooling method of merger accounting and 0 if the purchase method is employed. Post-merger performance may vary with the type of merger accounting method that acquirers use (Ravenscraft and Scherer 1989). Specifically, under the purchase method, any difference between the purchase price and the market value of an asset is recorded as goodwill. No marking to market occurs and, consequently, no goodwill is recorded under the pooling method. As a result, merger-related expenses are likely to be lower under the pooling method. ${ }^{14,15}$

Table 7 presents the results of the regression specifications for years 1 to 5 . The table shows that, consistent with our expectations, more concentrated markets are associated with lower post-merger performance and more profitable banking sectors lead to gains in market-adjusted OPCFROA. The coefficients on both variables remain significant at the $1 \%$ level for each of the five years following

\footnotetext{
${ }^{14}$ Starting from 2001, all acquisitions under US GAAP must be accounted for using the purchase method of accounting. Similar rules apply under IFRS since 2005. However, even before 2005, pooling was very rarely applied outside the US and the conditions for its application were restricted. In Germany and the UK, for example, pooling was generally restricted to mergers where acquirers could not be clearly identified.

${ }^{15}$ Out of the 80 US transactions, 19 US institutions chose pooling accounting. The correlation coefficient between the pooling dummy and the US dummy is 0.35 (significant at 5\%) and multicollinearity between the two variables, hence, a negligible issue.
} 
M\&A. Similarly, the US dummy enters the regressions with a negative sign in year 1 as well as in each of the following years (significant at 1\%), thereby, lending further support to our earlier finding that European bank mergers outperform US M\&A activities in the post-merger period.

[Table 7 near here]

In contrast to the country sector concentration and sector profitability variables whose effect on market-adjusted OPCFROA becomes observable in year 1 and persists for all five years following M\&A, the profitability effect of variables whose values are linked to the outcome of the post-merger integration process varies during post-merger years. For example, Table 7 shows that low loan-loss provisions are associated with improvements in market-adjusted OPCFROA in years 1 and 2 (statistically significant at 5\%) and, to a smaller extent, in year 3 (significant at 10\%). This could be interpreted as evidence consistent with the post-merger increases in lending which often follow M\&A (see Knapp et al. 2005) causing higher loan loss reserves for some banks. However, in the years after a deal has been completedas banks’ loan approval procedures adapt to the increased volumes of activity — the negative influence of the loan loss variable on performance is no longer statistically significant. Similarly, employment cost exert a negative influence on market-adjusted returns only in year 1 (significant at 5\%) and year 2 (significant at 10\%), implying that merger-induced cost inefficiencies tend to be temporary. Accordingly, this result implies that it takes up to two years following M\&A for employment cost to be sharply reduced, the number of branches to be trimmed, and administrative processes to be streamlined.

The cross-border dummy does not enter any of the regressions at a customary level of statistical significance until year 4. The coefficient is positive-confirming our earlier finding that cross-border M\&A outperform domestic bank mergers — and significant at 5\% for years 4 and 5 . Consequently, it takes up to three years for the performance gains of cross-border M\&A to come into effect. Further, the coefficient on the pooling method dummy is not statistically significant implying that the performance results are not influenced by the method of takeover accounting chosen. 
Finally, at a more general level, it should be pointed out that the similar regression coefficients across the five post-merger years in Table 7 lend robustness to the conclusions drawn from them. The signs on the coefficients remain identical across years for almost all cases. Also, the high adjusted R-squared values indicate that the specifications used explain a high share of the variation in performance-adjusted OPCFROA in the post-merger period.

\section{$6 \quad$ Concluding Remarks}

Banking has undergone dynamic and structural changes on a scale experienced by few industries in modern times. Competition from financial markets and other non-bank financial institutions has eroded banks' traditional role as financial intermediaries, while deregulation, advances in communication technologies, and demand from savers wishing to deploy assets more efficiently have opened up new business opportunities for banks. While the reasons behind M\&A most frequently cited by bank managers are cost-cutting and revenue enhancements, no attempts have been made in the literature to link postmerger strategies to the performance of bank mergers across different countries.

In this paper, we analyze the strategies underlying bank M\&A in Europe and the US. We contrast merger activities in the US to those of European institutions, because Europe is the second most active M\&A market. Further, there are political pressures from the European Union (EU) for a more integrated European banking sector with positive implications for the effectiveness of monetary policy across the Euro area (by reducing interest rate pass-through times in retail financial services) and potentially reduced cross-border banking fees (Goddard et al. 2007).

Inferring ex-ante merger strategies from ex-post accounting data, we show that banks in Europe seek to raise efficiency levels in the post-merger period, while scaling back on lending activities. US banks adopt a strategy consistent with post-merger revenue enhancements in the form of increased interest and non-interest income, which, however, is associated with lower post-merger efficiency. We argue that our accounting analysis shows that banks in the US follow a strategy of revenue-enhancements as they 
capitalize on recent regulatory changes which permit the formation of integrated financial services firms, while European banks pursue a cost cutting strategy, possibly in response to growing investor pressures. We find that M\&A leads to performance gains for European banks in the years following a merger. By contrast, in the US, there is no evidence of M\&A affecting the performance of acquiring institutions. This is consistent with explanations that revenue-enhancing strategies lead to lower productivity as the provision of additional services raise costs overall.

The relatively positive performance effects of European bank mergers (and European cross-border mergers in particular) add legitimacy to policy initiatives at the EU-level that are designed to facilitate the pan-European consolidation of credit institutions. However, the fact that bank mergers in the US do not lead to performance gains raises possible governance explanations behind M\&A (see Becher and Campbell 2004; Hagendorff et al. 2007). If banks that engage in M\&A do not outperform those that did not, the question arises as to why shareholders (as well as bondholders and other stakeholders) are exposed to the substantial risk of value destruction inherent in an M\&A bid. Our finding that US bank mergers are performance neutral demonstrates that, despite years of research, the theoretical framework underpinning bank M\&A may only partly explain the performance effects of such activities. 


\section{REFERENCES}

Akhavein, J. D., A. N. Berger, and D. B. Humphrey, 1997, The effects of megamergers on efficiency and prices: Evidence from a bank profit function, Review of Industrial Organization 12, 95-139.

Allen, F., and W. L. Song, 2005, Financial integration and EMU, European Financial Management 11, 724.

Altunbas, Y., and D. M. Ibanez, 2004, Mergers and acquisitions and bank performance in europe. The role of strategic similarities, ECB Working Paper Series No. 398, European Central Bank. Frankfurt, Germany.

Amel, D., C. Barnes, F. Panetta, and C. Salleo, 2004, Consolidation and efficiency in the financial sector: A review of the international evidence, Journal of Banking \& Finance 28, 2493-2519.

Amihud, Y., G. L. DeLong, and A. Saunders, 2002, The effects of cross-border bank mergers on bank risk and value, Journal of International Money and Finance 21, 857-877.

Amihud, Y., and B. Lev, 1981, Risk reduction as a managerial motive for conglomerate mergers, Bell Journal of Economics 12, 605-617.

Barber, B. M., and J. D. Lyon, 1996, Detecting abnormal operating performance: The empirical power and specification of test statistics, Journal of Financial Economics 41, 359-399.

Becher, D. A., and T. L. Campbell, 2004, Corporate governance of bank mergers, Proceedings - Federal Reserve Bank of Chicago, 267-287.

Berger, A. N., R. S. Demsetz, and P. E. Strahan, 1999, The consolidation of the financial services industry: Causes, consequences, and implications for the future, Journal of Banking \& Finance 23, 135-194.

Berger, A. N., and R. DeYoung, 2001, The effects of geographic expansion on bank efficiency, Journal of Financial Services Research 19, 163-184.

Berger, A. N., and L. J. Mester, 1997, Inside the black box: What explains differences in the efficiencies of financial institutions?, Journal of Banking \& Finance 21, 895-947.

Berger, A. N., and L. J. Mester, 2003, Explaining the dramatic changes in performance of US banks: Technological change, deregulation, and dynamic changes in competition, Journal of Financial Intermediation 12, 57-95.

Berger, A. N., A. Saunders, J. M. Scalise, and G. F. Udell, 1998, The effects of bank mergers and acquisitions on small business lending, Journal of Financial Economics 50, 187-229.

Bikker, J. A., and K. Haaf, 2002, Competition, concentration and their relationship: An empirical analysis of the banking industry, Journal of Banking \& Finance 26, 2191-2214.

Bos, J. W. B., and J. W. Kolari, 2005, Large bank efficiency in europe and the united states: Are there economic motivations for geographic expansion in financial services?, Journal of Business 78, 15551592. 
Campa, J. M., and I. Hernando, 2004, Shareholder value creation in european M\&As, European Financial Management 10, 47-81.

Campa, J. M., and I. Hernando, 2006, M\&As performance in the european financial industry, Journal of Banking \& Finance 30, 3367-3392.

Campa, J. M., and S. Kedia, 2002, Explaining the diversification discount, Journal of Finance 57, 17311762.

Cornett, M., H. Mehran, and H. Tehranian, 1998, Are financial markets overly optimistic about the prospects of firms that issue equity? Evidence from voluntary versus involuntary equity issuances by banks, Journal of Finance 53, 2139-2159.

Cornett, M. M., J. J. McNutt, and H. Tehranian, 2006, Performance changes around bank mergers: Revenue enhancements versus cost reductions, Journal of Money, Credit, and Banking 38, 1013.

DeLong, G., 2003, Does long-term performance of mergers match market expectations? Evidence from the US banking industry, Financial Management 32, 5-25.

DeLong, G., and R. DeYoung, 2007, Learning by observing: Information spillovers in the execution and valuation of commercial bank M\&As, Journal of Finance 62, 181-216.

Eisenbeis, R. A., and G. G. Kaufman, 2006, Cross-border banking: Challenges for deposit insurance and financial stability in the european union, Federal Reserve Bank of Atlanta Working Paper No. 2006-15.

Focarelli, D., F. Panetta, and C. Salleo, 2002, Why do banks merge?, Journal of Money, Credit, and Banking 34, 1047-1066.

Focarelli, D., and A. F. Pozzolo, 2001, The patterns of cross-border bank mergers and shareholdings in OECD countries, Journal of Banking \& Finance 25, 2305-2337.

Ghosh, A., 2001, Does operating performance really improve following corporate acquisitions?, Journal of Corporate Finance 7, 151-178.

Goddard, J., P. Molyneux, J. O. S. Wilson, and M. Tavakoli, 2007, European banking: An overview, Journal of Banking \& Finance 31, 1911-1935.

Hagendorff, J., M. Collins, and K. Keasey, 2007, Bank governance and acquisition performance, Corporate Governance - An International Review 15, 957-968.

Healy, P. M., K. G. Palepu, and R. S. Ruback, 1992, Does corporate performance improve after mergers, Journal of Financial Economics 31, 135-175.

Houston, J. F., C. M. James, and M. D. Ryngaert, 2001, Where do merger gains come from? Bank mergers from the perspective of insiders and outsiders, Journal of Financial Economics 60, 285-331.

Houston, J. F., and M. D. Ryngaert, 1994, The overall gains from large bank mergers, Journal of Banking \& Finance 18, 1155-1176.

Hughes, J. P., W. W. Lang, L. J. Mester, C. G. Moon, and M. S. Pagano, 2003, Do bankers sacrifice value to build empires? Managerial incentives, industry consolidation, and financial performance, Journal of Banking \& Finance 27, 417-447. 
Kiymaz, H., 2004, Cross-border acquisitions of US financial institutions: Impact of macroeconomic factors, Journal of Banking \& Finance 28, 1413-1439.

Klein, P. G., and M. R. Saidenberg, 2005, Organizational structure and the diversification discount: Evidence from commercial banking, CORI Working Paper No. 2005-06.

Knapp, M., A. Gart, and D. Becher, 2005, Post-merger performance of bank holding companies, 19871998, The Financial Review 40, 549-574.

Knapp, M., A. Gart, and M. Chaudhry, 2006, The impact of mean reversion of bank profitability on postmerger performance in the banking industry, Journal of Banking \& Finance 30, 3503-3517.

Lindner, J., and D. Crane, 1993, Bank mergers: Integration and profitability, Journal of Financial Services Research 7, 35-55.

Loughran, T., and J. R. Ritter, 1997, The operating performance of firms conducting seasoned equity offerings, Journal of Finance 52, 1823-1850.

Lubatkin, M., 1983, Mergers and the performance of the acquiring firm, Academy of Management Review 8, 218-225.

Ramaswamy, K., 1997, The performance impact of strategic similarity in horizontal mergers: Evidence from the u.S. Banking industry, Academy of Management Journal 40, 697-715.

Ravenscraft, D. J., and F. M. Scherer, 1989, The profitability of mergers, International Journal of Industrial Organization 7, 101-116.

Rhoades, S. A., 1994, A summary of merger performance studies in banking, 1980-93, and an assessment of the operating performance and event study methodologies, Federal Reserve Board - Staff Study 167, Federal Reserve Bank.

Rhoades, S. A., 1998, The efficiency effects of bank mergers: An overview of case studies of nine mergers, Journal of Banking \& Finance 22, 273-291.

Shleifer, A., and R. W. Vishny, 2003, Stock market driven acquisitions, Journal of Financial Economics 70, 295-311.

Vander Vennet, R., 1996, The effect of mergers and acquisitions on the efficiency and profitability of EC credit institutions, Journal of Banking \& Finance 20, 1531-1558.

White, H., 1980, A heteroskedasticity-consistent covariance matrix estimator and a direct test for heteroskedasticity, Econometrica 48, 817-838

White, W. R., 1998, The coming transformation of continental european banking?, Bank for International Settlements Working Papers, No. 54.

Zollo, M., and H. Singh, 2004, Deliberate learning in corporate acquisitions: Post-acquisition strategies and integration capability in US bank mergers, Strategic Management Journal 25, 1233-1256. 
Table 1 Number of Bank Acquisitions by Country and Year

\begin{tabular}{|c|c|c|c|c|c|}
\hline \multicolumn{3}{|c|}{ M\&A by Geographic Origin of the Acquiring Bank } & \multicolumn{3}{|c|}{ Number of M\&A by Merger Completion Years } \\
\hline Acquirer country & Frequency & $\%$ of Sample & Year & Frequency & $\%$ of Sample \\
\hline Belgium & 6 & 5.31 & 1996 & 1 & 0.88 \\
\hline Denmark & 1 & 0.88 & 1997 & 14 & 12.39 \\
\hline France & 4 & 3.54 & 1998 & 11 & 9.73 \\
\hline Germany & 2 & 1.77 & 1999 & 12 & 10.62 \\
\hline Italy & 5 & 4.42 & 2000 & 19 & 16.81 \\
\hline Netherlands & 2 & 1.77 & 2001 & 15 & 13.27 \\
\hline Spain & 3 & 2.65 & 2002 & 15 & 13.27 \\
\hline Sweden & 1 & 0.88 & 2003 & 5 & 4.42 \\
\hline Switzerland & 1 & 0.88 & 2004 & 17 & 15.04 \\
\hline United Kingdom & 8 & 7.08 & 2005 & 4 & 3.54 \\
\hline United States & 80 & 70.8 & & & \\
\hline Total & 113 & 100 & Total & 113 & 100 \\
\hline
\end{tabular}




\section{Table 2 Performance Ratios around Bank M\&A}

The list of ratios below are used to analyze the financial components of acquiring bank's operating performance. Bankscope Code refers to the codes used for balance sheet and income statement items in Fitch's Bankscope database. AVG denotes averages per accounting year.

\begin{tabular}{|c|c|c|}
\hline Data Item & Bankscope Code & Explanation \\
\hline \multicolumn{3}{|l|}{ Profitability } \\
\hline return on average assets (ROAA) & 2115 / 2025AVG & \\
\hline return on average equity (ROAE) & 2115 / 2055AVG & \\
\hline net interest margin & 2080 / 2010AVG & net interest income/earning assets \\
\hline net int rev / avg assets & 4019 & \\
\hline non-interest income / tot assets & $(6540+6570+6600+6630) / 5670$ & \\
\hline non-interest income / op income & $(6540+6570+6600+6630) / 6640$ & \\
\hline other operat income / assets & 2085 / 2025AVG & \\
\hline \multicolumn{3}{|l|}{ Efficiency } \\
\hline cost to income ratio & $2090 /(2080+2085)$ & overheads / net income \\
\hline $\begin{array}{l}\text { employment cost / operating } \\
\text { expenses }\end{array}$ & $6650 / 6710$ & \\
\hline $\begin{array}{l}\text { employment cost / non interest } \\
\text { expenses }\end{array}$ & $6650 /(6540+6570+6600+6630)$ & \\
\hline employment cost per employee & $6650 / 7180$ & \\
\hline $\begin{array}{l}\text { non-interest expenses / no of } \\
\text { employees }\end{array}$ & $(6550+6580+6610+6650+6660+6670) / 7180$ & \\
\hline operat expense / no of employees & $6710 / 7180$ & \\
\hline non-interest expense / operat income & $(6550+6580+6610+6650+6660+6670) / 7470$ & $\begin{array}{l}\text { non interest income = trading, } \\
\text { commission, other operat income }\end{array}$ \\
\hline \multicolumn{3}{|l|}{ Asset Quality } \\
\hline net loans / total assets & $2000 / 2025$ & \\
\hline deposits / assets & $2030 / 2025$ & \\
\hline loan loss prov / net loans & $6690 / 5330$ & \\
\hline loan loss reserve / gross loans & $2070 /(2000+2070)$ & \\
\hline loan loss prov / net int rev & 2095 / 2080 & \\
\hline tier 1 capital ratio & 7040 & \\
\hline total capital ratio & 7050 & \\
\hline equity / total assets & 4009 & \\
\hline
\end{tabular}


Table 3 Market-adjusted Accounting Data around Bank M\&A, by Location of the Bidding Bank

The accounting ratios are compiled using Fitch's Bankscope database. Data are measured against mean values of listed banks (net sample banks) that are domiciled in the same country as the acquirer. Values are expressed in \%, apart from employment cost, non-interest expenses, operating expenses, and non-interest expenses. Currency conversions from non-USD values mast

\begin{tabular}{|c|c|c|c|c|c|c|c|c|c|c|c|c|}
\hline \multirow{3}{*}{$\begin{array}{l}\text { Performance Metric } \\
\text { profitability } \\
\text { return on average assets (ROAA) }\end{array}$} & \multicolumn{5}{|c|}{ Europe } & & \multicolumn{6}{|c|}{ US } \\
\hline & \multicolumn{2}{|c|}{$\begin{array}{c}\text { Pre-merger } \\
(t-1)\end{array}$} & \multicolumn{2}{|c|}{$\begin{array}{l}\text { Post-merger } \\
(t+3)\end{array}$} & Difference & & \multicolumn{2}{|c|}{$\begin{array}{c}\text { Pre-merger } \\
(t-1)\end{array}$} & \multicolumn{2}{|c|}{$\begin{array}{l}\text { Post-merger } \\
\quad(t+3)\end{array}$} & \multicolumn{2}{|l|}{ Difference } \\
\hline & & & & & & & & & & & & \\
\hline net int rev / avg assets & $-0.59 \%$ & $* * *$ & $-0.28 \%$ & & $0.31 \%$ & & $0.06 \%$ & & $0 \%$ & & $-0.06 \%$ & \\
\hline non-interest income / tot assets & $-2.52 \%$ & *** & $-2.86 \%$ & *** & $-0.34 \%$ & & $-1.21 \%$ & *** & $-0.89 \%$ & *** & $0.32 \%$ & \\
\hline non-interest income / operating income & $-1.13 \%$ & & $-7.43 \%$ & * & $-6.31 \%$ & & $1.95 \%$ & & $5.77 \%$ & *** & $3.82 \%$ & * \\
\hline oth op inc / avg assets & $-2.55 \%$ & *** & $-2.76 \%$ & $* * *$ & $-0.21 \%$ & & $-1.19 \%$ & $* * *$ & $-0.85 \%$ & $* * *$ & $0.34 \%$ & * \\
\hline \multicolumn{13}{|l|}{ cost efficiency } \\
\hline cost to income ratio & $-1.25 \%$ & & $-4.31 \%$ & & $-3.07 \%$ & * & $2.73 \%$ & $* * *$ & $4.41 \%$ & $* * *$ & $1.68 \%$ & \\
\hline employment cost / operating expenses & $-4.1 \%$ & ** & $-5.03 \%$ & ** & $-0.93 \%$ & & $2.95 \%$ & *** & $4.01 \%$ & *** & $1.06 \%$ & \\
\hline employment cost / non interest exp. & $-4.28 \%$ & ** & $-5.74 \%$ & *** & $-1.46 \%$ & & $3 \%$ & $* * *$ & $3.66 \%$ & *** & $0.65 \%$ & \\
\hline employment cost per employee (000s) & -18.93 & * & -29.15 & * & -10.22 & ** & -1.00 & & 1.02 & *** & 2.02 & $* *, \dagger$ \\
\hline non-interest expenses / no of employees & -40.94 & $* * *$ & -53.8 & *** & -12.86 & ** & -2.03 & & 0.1 & & 2.13 & * \\
\hline non int exp / avg assets & $-2.2 \%$ & *** & $-2.48 \%$ & *** & $-0.28 \%$ & & $-1.11 \%$ & $* * *$ & $-0.99 \%$ & *** & $0.12 \%$ & \\
\hline \multicolumn{13}{|l|}{ asset quality } \\
\hline net loans / total assets & $-3.86 \%$ & ** & $-7.03 \%$ & *** & $-3.17 \%$ & * & $1.71 \%$ & & $2.89 \%$ & & $1.18 \%$ & $* *, \dagger$ \\
\hline deposits / assets & $1.77 \%$ & & $0.82 \%$ & & $-0.95 \%$ & & $0.89 \%$ & & $0.52 \%$ & & $-0.37 \%$ & \\
\hline loan loss prov / net loans & $0.02 \%$ & & $-0.63 \%$ & & $-0.65 \%$ & & $0.04 \%$ & & $0.08 \%$ & & $0.04 \%$ & \\
\hline loan loss reserve / gross loans & $-1.18 \%$ & *** & $-1.29 \%$ & ** & $-0.11 \%$ & & $0.1 \%$ & * & $0.06 \%$ & & $-0.04 \%$ & \\
\hline loan loss prov / net int rev & $3.96 \%$ & * & $5.06 \%$ & * & $1.1 \%$ & & $-0.18 \%$ & & $0.87 \%$ & & $1.04 \%$ & \\
\hline tier 1 capital ratio & $-6.46 \%$ & $* * *$ & $-2.82 \%$ & ** & $3.64 \%$ & & $-2.85 \%$ & $* * *$ & $-2.41 \%$ & *** & $0.44 \%$ & \\
\hline total capital ratio & $-4.9 \%$ & $* * *$ & $-1.97 \%$ & ** & $2.93 \%$ & ** & $-1.67 \%$ & $* * *$ & $-1.44 \%$ & $* * *$ & $0.22 \%$ & \\
\hline equity / total assets & $-5.51 \%$ & ** & $0.91 \%$ & & $6.41 \%$ & & $-1.5 \%$ & *** & $-1.73 \%$ & $* * *$ & $-0.22 \%$ & \\
\hline
\end{tabular}

$*(* *, * * *)$ significant at $10 \%(5 \%$; and $1 \%)$ according to a $t$-statistic. 
$-$ 
Table 4 Post-merger Performance of European and US Banks

The sample consists of 113 publicly traded banking firms in Europe (EU-15) and the US that completed majority acquisitions worth at least $\$ 100$ mill (in constant 2004 USD) between 1996 and 2005. Performance data are presented relative to the year of merger completion ( $t=0)$ and measured against performance-matched banks and against asset-weighted industry averages. The performance metric is operating cash flows returns on assets (OPCFROA) which is pre-tax operating cash flows divided by the book value of assets (where pre-tax operating cash flows are income before taxes and extraordinary items plus debt expenses). Data are from Worldscope. Reported values are mean values. -1 to +3

Panel A: $\triangle O P C F R O A$ US Banks $(n=80)$

\begin{tabular}{|c|c|c|c|c|c|c|c|}
\hline & performance & $1.99 \%$ & $2.08 \%$ & $2.04 \%$ & $2.26 \%$ & $2.33 \%$ & \\
\hline Market & control & $1.42 \%$ & $1.55 \%$ & $1.67 \%$ & $1.61 \%$ & $1.79 \%$ & $0.01 \%$ \\
\hline Adjusted & abnormal & $0.56 \%{ }^{* * *, \dagger}$ & $0.53 \%^{* * *, \dagger}$ & $0.37 \%^{* * *, \dagger}$ & $0.65 \%^{* * *, \dagger}$ & $0.54 \%$ *** & \\
\hline Performance & control & $2.21 \%$ & $2.18 \%$ & $2.29 \%$ & $2.27 \%$ & $2.25 \%$ & $0.19 \%$ \\
\hline Adjusted & abnormal & $-0.22 \%$ & $-0.10 \%$ & $-0.25 \%^{* *, \dagger}$ & $-0.01 \%$ & $0.09 \%$ & \\
\hline
\end{tabular}

Panel B: $\triangle O P C F R O A$ European Banks ( $n=33)$

\begin{tabular}{|c|c|c|c|c|c|c|c|}
\hline & performance & $2.08 \%$ & $2.07 \%$ & $1.94 \%$ & $1.75 \%$ & $1.59 \%$ & \\
\hline Market & control & $3.88 \%$ & $3.58 \%$ & $2.97 \%$ & $2.76 \%$ & $2.84 \%$ & $1.23 \%^{* *,+}$ \\
\hline adjusted & abnormal & $-1.80 \%^{* *,+\dagger}$ & $-2.51 \%^{* *, \dagger}$ & $-1.03 \%$ & $-1.01 \%$ & $-1.28 \%$ & \\
\hline Performance & control & $3.22 \%$ & $3.67 \%$ & $2.37 \%$ & $2.33 \%$ & $2.20 \%$ & $1.01 \%^{*, \dagger}$ \\
\hline adjusted & abnormal & $-1.15 \%{ }^{*}, \dagger$ & $-1.60 \%{ }^{* *, \dagger}$ & $-0.43 \%$ & $-0.58 \%$ & $-0.60 \%$ & \\
\hline
\end{tabular}

**** ***, and ${ }^{*}$ denote statistical significance at the $1 \%, 5 \%$ and $10 \%$ levels, according to a two-tailed $t$-test.

${ }^{\dagger}$ denotes statistical significance at least at $5 \%$ based on a Wilcoxon signed-rank test. 
Table 5 Post-Merger Performance of Cross-border and Domestic Bank Mergers

The sample consists of 113 publicly traded banking firms in Europe (EU-15) and the US that completed majority acquisitions worth at least \$100 mill (in constant 2004 USD) between 1996 and 2005. Performance data are presented relative to the year of merger completion $(t=0)$ and measured against performance-matched banks and against asset-weighted industry averages. The performance metric is operating cash flows returns on assets (OPCFROA) which is pre-tax operating cash flows divided by the book value of assets (where pre-tax operating cash flows are income before taxes and extraordinary items plus debt expenses). Cross-border mergers involve bidders and targets being chartered in different countries. Data are from Worldscope. Reported values are mean values.

\begin{tabular}{|c|c|c|c|c|}
\hline \multirow{2}{*}{$\begin{array}{c}\text { Years to } \\
\text { Merger } \\
(t=0)\end{array}$} & \multirow{2}{*}{$\begin{array}{c}\text { Bidding } \\
\text { Banks }\end{array}$} & Control Group & $\begin{array}{c}\text { AOPCFROA: } \\
\text { bidder-control }\end{array}$ & $\triangle$ OPCFROA : -1 to +3 \\
\hline & & performance market & performance market & performance market \\
\hline
\end{tabular}

Panel A: OPCFROA for domestic mergers in the US $(n=80)$

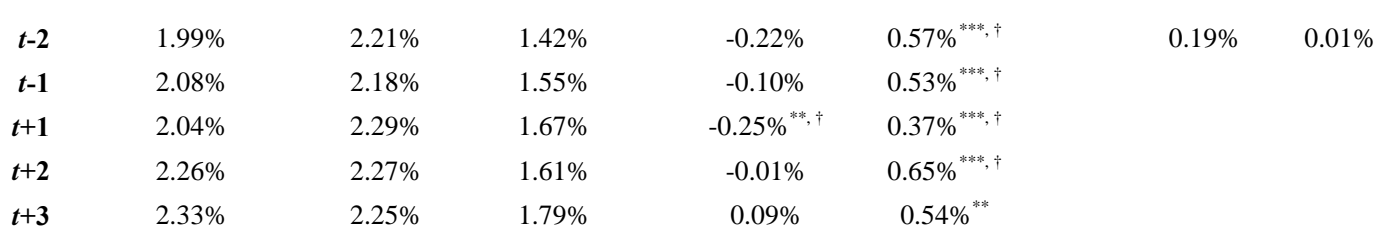

Panel B: OPCFROA for domestic mergers in Europe (n=12)

$\begin{array}{rlllllll}\boldsymbol{t}-\mathbf{2} & 1.79 \% & 3.09 \% & 3.12 \% & -1.30 \% & -1.30 \%^{*} & -0.01 \% & 0.00 \% \\ \boldsymbol{t}-\mathbf{1} & 1.87 \% & 3.09 \% & 3.08 \% & -1.22 \% & -1.22 \% & & \\ \boldsymbol{t}+\mathbf{1} & 1.89 \% & 2.40 \% & 2.97 \% & -0.50 \% & -0.51 \% & \\ \boldsymbol{t}+\mathbf{2} & 1.78 \% & 2.45 \% & 2.63 \% & -0.67 \% & -0.65 \% & \\ \boldsymbol{t}+\mathbf{3} & 1.54 \% & 2.76 \% & 2.12 \% & -1.23 \% & -1.22 \% & \end{array}$

Panel C: OPCFROA for cross-border mergers (n=21, all European acquirers)

\begin{tabular}{|c|c|c|c|c|c|c|c|}
\hline$t-2$ & $2.29 \%$ & $3.32 \%$ & $5.70 \%$ & $-1.03 \%{ }^{* *}$ & $-3.41 \%{ }^{* * *}$ & $1.68 \%{ }^{*}, \dagger$ & $1.31 \%$ \\
\hline$t-1$ & $2.22 \%$ & $4.08 \%$ & $5.27 \%$ & $-1.86 \%{ }^{* *, \dagger}$ & $-3.05 \%{ }^{* *}$ & & \\
\hline$t+1$ & $1.96 \%$ & $2.35 \%$ & $2.90 \%$ & $-0.39 \%$ & $-0.94 \%$ & & \\
\hline$t+2$ & $1.73 \%$ & $1.92 \%$ & $2.85 \%$ & $-0.19 \%$ & $-1.12 \%$ & & \\
\hline$t+3$ & $1.63 \%$ & $1.81 \%$ & $3.36 \%$ & $-0.18 \%$ & $-1.73 \%$ & & \\
\hline
\end{tabular}

${ }^{* * * *},{ }^{* *}$, and ${ }^{*}$ denote statistical significance at the $1 \%, 5 \%$ and $10 \%$ levels, according to a two-tailed $t$-test.

${ }^{\dagger}$ denotes statistical significance at least at $5 \%$ based on a Wilcoxon signed-rank test. 
Table 6 Performance Implications of Product Focus and Diversifying Bank Mergers

The sample consists of 113 publicly traded banking firms in Europe (EU-15) and the US that completed majority acquisitions worth at least \$100 mill (in constant 2004 USD) between 1996 and 2005. Performance data are presented relative to the year of merger completion $(t=0)$ and measured against performance-matched banks and against asset-weighted industry averages. The performance metric is operating cash flows returns on assets (OPCFROA) which is pre-tax operating cash flows divided by the book value of assets (where pre-tax operating cash flows are income before taxes and extraordinary items plus debt expenses). Product-focusing mergers involve banks where the first two digits of the four-digit SIC code of the main product line are identical. Data are from the Worldscope database. Reported values are mean values.

\begin{tabular}{|c|c|c|c|c|c|c|c|c|}
\hline & & $t-2$ & $t-1$ & $t+1$ & $t+2$ & $t+3$ & \multicolumn{2}{|c|}{$\begin{array}{c}\triangle O P C F R O A \\
\text { years }-1 \text { to }+3\end{array}$} \\
\hline \multicolumn{9}{|c|}{ Panel A: OPCFROA US Banks $(n=80)$} \\
\hline focusing & market-adjusted & $0.60 \%{ }^{* * *}, \dagger$ & ${ }_{\dagger}^{0.48 \%} \%^{* * *}$ & $0.47 \%^{* * *+} \dagger$ & $0.64 \%^{* * *}$ & ${ }_{\dagger}^{0.52 \%}{ }^{* * *}$ & $0.06 \%$ & \\
\hline$(n=69)$ & performance-adjusted & $-0.25 \%{ }^{* *}$ & $-0.06 \%$ & $-0.27 \%$ & $-0.06 \%$ & $0.01 \%$ & $0.07 \%$ & \\
\hline diversifying & market-adjusted & $0.33 \%{ }^{*}$ & $0.76 \%{ }^{* *, \dagger}$ & $0.59 \%^{* * *, \dagger}$ & ${ }_{\dagger}^{0.78 \%} \%^{* * *}$ & $0.42 \%{ }^{*}$ & $-0.33 \%$ & \\
\hline$(n=11)$ & performance-adjusted & $-0.07 \%$ & $-0.34 \%$ & $-0.10 \%$ & $0.28 \%$ & $0.42 \%$ & $0.76 \%$ & \\
\hline \multicolumn{9}{|c|}{ Panel B: OPCFROA European Banks (n=33) } \\
\hline focusing & market-adjusted & $-2.04 \%{ }^{* *}$ & $-1.83 \%{ }^{* *}$ & $0.83 \%$ & $-0.95 \%{ }^{*}$ & $-0.79 \%$ & $1.04 \%$ & \\
\hline$(n=21)$ & performance-adjusted & $-1.26 \%{ }^{* *}$ & $-\overline{2.03 \%^{* *, \dagger}}$ & $-1.34 \%{ }^{* *}$ & $-0.82 \%$ & $-1.96 \%$ & $0.07 \%$ & \\
\hline diversifying & market-adjusted & $-2.88 \%{ }^{* *}$ & $-3.61 \%^{* *}$ & $-1.30 \%$ & $-1.13 \%$ & $-2.35 \%$ & $1.25 \%$ & \\
\hline$(n=12)$ & performance adjusted & $-2.28 \%{ }^{* *}$ & $-4.41 \%^{* *}$ & $-0.25 \%$ & $2.86 \%$ & $-0.17 \%$ & $4.24 \%$ & ${ }^{* *,+}$ \\
\hline
\end{tabular}

${ }^{* * * * * *}$, and ${ }^{*}$ denote statistical significance at the $1 \%, 5 \%$ and $10 \%$ levels, according to a two-tailed $t$-test.

${ }^{\dagger}$ denotes statistical significance at least at $5 \%$ based on a Wilcoxon signed-rank test. 
Table 7 Regression Results: Performance Changes around Bank Mergers

The dependent variable are market-adjusted OPCFROA (mean values). Accounting data for banks are from Fitch's Bankscope database. Deal specifics are from Thomson Financial.. Relative size is defined as target over acquirer assets (in $t-1$ ). Deal value is the logarithm of the dollar value of the M\&A transaction and cash finance is a dummy which is 1 if a transaction is $100 \%$ cash-financed and 0 otherwise. Cross-border is a dummy variable that takes the value of 1 for acquisitions where target and acquirers are located in different countries; target profitability is ROA in $t-1$; product focus is measured by a binary variable that takes the value of 1 if the first two digits of the six-digit SIC code of the companies in a merger are identical and 0 otherwise. Concentration and is share of assets of the three largest credit institutions and net interest margin the average value of net interest revenue over total earning assets (both in the target country).

\begin{tabular}{|c|c|c|c|c|}
\hline & $t+1$ & $t+2$ & $t+3$ & $t+4$ \\
\hline net loans / total assets & $\begin{array}{l}0.039 * * \\
(0.016)\end{array}$ & $\begin{array}{l}0.001 \\
(0.018)\end{array}$ & $\begin{array}{l}0.012 \\
(0.019)\end{array}$ & $\begin{array}{l}-0.016 \\
(0.029)\end{array}$ \\
\hline employment cost / operating expenses & $\begin{array}{l}-0.022^{* *} \\
(0.011)\end{array}$ & $\begin{array}{l}-0.029 * \\
(0.016)\end{array}$ & $\begin{array}{l}-0.024 \\
(0.016)\end{array}$ & $\begin{array}{l}-0.011 \\
(0.018)\end{array}$ \\
\hline rel. size & $\begin{array}{l}-0.512 \\
(0.446)\end{array}$ & $\begin{array}{l}-0.400 \\
(0.443)\end{array}$ & $\begin{array}{l}-0.624 \\
(0.432)\end{array}$ & $\begin{array}{l}-0.770 \\
(0.604)\end{array}$ \\
\hline non-interest income / operating income & $\begin{array}{l}-0.003 \\
(0.011)\end{array}$ & $\begin{array}{l}-0.007 \\
(0.012)\end{array}$ & $\begin{array}{l}-0.006 \\
(0.012)\end{array}$ & $\begin{array}{l}0.009 \\
(0.016)\end{array}$ \\
\hline deal value & $\begin{array}{l}0.211^{*} \\
(0.114)\end{array}$ & $\begin{array}{l}0.199 \\
(0.170)\end{array}$ & $\begin{array}{l}0.181 \\
(0.166)\end{array}$ & $\begin{array}{l}-0.105 \\
(0.244)\end{array}$ \\
\hline loan loss provisions / net int. rev & $\begin{array}{l}-0.047^{* *} \\
(0.022)\end{array}$ & $\begin{array}{l}-0.040^{* *} \\
(0.021)\end{array}$ & $\begin{array}{l}-0.042^{*} \\
(0.023)\end{array}$ & $\begin{array}{l}-0.034 \\
(0.029)\end{array}$ \\
\hline cash finance & $\begin{array}{l}-0.660 \\
(0.422)\end{array}$ & $\begin{array}{l}-0.859^{*} \\
(0.456)\end{array}$ & $\begin{array}{l}-0.999 * * \\
(0.453)\end{array}$ & $\begin{array}{l}-1.413^{* *} \\
(0.685)\end{array}$ \\
\hline cross-border dummy & $\begin{array}{l}1.136^{*} \\
(0.598)\end{array}$ & $\begin{array}{l}0.295 \\
(0.739)\end{array}$ & $\begin{array}{l}0.161 \\
(0.708)\end{array}$ & $\begin{array}{l}2.160^{* *} \\
(1.091)\end{array}$ \\
\hline US dummy & $\begin{array}{l}-3.953 * * * \\
(0.883)\end{array}$ & $\begin{array}{l}-3.163 * * * \\
(0.948)\end{array}$ & $\begin{array}{l}-3.225^{* * *} \\
(0.967)\end{array}$ & $\begin{array}{l}-4.964^{* * * *} \\
(1.614)\end{array}$ \\
\hline target ROA & $\begin{array}{l}-8.196 \\
(6.690)\end{array}$ & $\begin{array}{l}-4.072 \\
(6.584)\end{array}$ & $\begin{array}{l}-6.539 \\
(6.353)\end{array}$ & $\begin{array}{l}-14.344^{*} \\
(7.515)\end{array}$ \\
\hline product focus & $\begin{array}{l}0.105 \\
(0.400)\end{array}$ & $\begin{array}{l}0.164 \\
(0.430)\end{array}$ & $\begin{array}{l}0.274 \\
(0.415)\end{array}$ & $\begin{array}{l}-0.107 \\
(0.563)\end{array}$ \\
\hline bank sector concentration & $\begin{array}{l}-11.892^{* * *} \\
(2.089)\end{array}$ & $\begin{array}{l}-11.562 * * * \\
(2.297)\end{array}$ & $\begin{array}{l}-9.964 * * * \\
(2.206)\end{array}$ & $\begin{array}{l}-11.643^{* * *} \\
(2.878)\end{array}$ \\
\hline sector net interest margin & $\begin{array}{l}256.228 * * * \\
(48.396)\end{array}$ & $\begin{array}{l}269.152^{* * *} \\
(49.639)\end{array}$ & $\begin{array}{l}284.591 \text { *** } \\
(48.605)\end{array}$ & $\begin{array}{l}219.409 * * * \\
(60.085)\end{array}$ \\
\hline pooling of interests dummy & $\begin{array}{l}-0.081 \\
(0.398)\end{array}$ & $\begin{array}{l}-0.111 \\
(0.395)\end{array}$ & $\begin{array}{l}-0.185 \\
(0.385)\end{array}$ & $\begin{array}{l}-0.137 \\
(0.480)\end{array}$ \\
\hline constant & $\begin{array}{l}-5.032 * \\
(2.596)\end{array}$ & $\begin{array}{l}-3.342 \\
(2.839)\end{array}$ & $\begin{array}{l}-5.107^{*} \\
(2.810)\end{array}$ & $\begin{array}{l}2.780 \\
(3.756)\end{array}$ \\
\hline observations & 104 & 94 & 90 & 87 \\
\hline R-squared & 0.69 & 0.64 & 0.66 & 0.64 \\
\hline
\end{tabular}

* significant at $10 \%$; $* *$ significant at $5 \%$; *** significant at $1 \%$. 